\section{Nutrients and Pesticides in Stormwater Runoff and Soil Water in Production Nurseries and Citrus and Avocado Groves in California}

\author{
Salvatore S. Mangiafico ${ }^{1}$, Julie Newman ${ }^{2,4}$, Donald J. Merhaut ${ }^{3}$, \\ Jay $\mathrm{Gan}^{1}$, Ben Faber ${ }^{2}$, and Laosheng $\mathrm{Wu}^{1}$
}

AdDITIONAL INDEX WORDS. nitrate, nitrogen, phosphorus, pyrethroid, organophosphate, organochlorine

$\overline{\text { SuMMARY. Potential water quality impacts of agricultural production include runoff }}$ and leaching losses of nutrients, pesticides, and sediment. Stormwater runoff and soil water samples were collected from citrus (Citrus spp.), avocado (Persea americana), and ornamental nursery sites in Ventura County, CA, across 19 months. Nitrate-nitrite-nitrogen concentrations in runoff ranged from 0.07 to $31.1 \mathrm{mg} \cdot \mathrm{L}^{-1}$, with medians for groves and nurseries of 4.2 and $5.7 \mathrm{mg} \cdot \mathrm{L}^{-1}$, respectively. Constituents in runoff exceeding benchmarks for surface waters included turbidity, chlorpyrifos, and some organochlorine pesticides. When detected, chlorpyrifos concentration was linearly related to sample turbidity $(P=$ $\left.0.0025, r^{2}=0.49\right)$. This suggests that the retention of waterborne sediments on-site may be an effective method for mitigating runoff of this pesticide. Bifenthrin, permethrin, and diazinon were also detected in runoff, but concentrations did not exceed water quality benchmarks. Nutrient concentrations in soil water were generally similar to nutrient concentrations in stormwater runoff, suggesting that potential groundwater contamination from leaching at citrus, avocado, and nursery sites may be as much of a concern as stormwater from these operations, particularly on sites with sandy or structured soil texture or flat topography. Nitrate-nitritenitrogen and orthophosphate concentrations in soil water were linearly related to nitrogen and phosphorus fertilizer application rates across sites, respectively $\left(P<0.0001, v^{2}=0.49\right.$ and 0.50 , respectively $)$, suggesting that proper nutrient management is important in reducing potential groundwater contamination at these operations.

$\mathrm{C}$ itrus, avocado, and ornamental nursery products are notable agricultural commodities in at least 12 counties throughout southern California, including coastal and inland areas [California Department of Food and Agriculture (CDFA), 2007. Nursery products, orange ( Citrus sinensis), lemon (Citrus limon), and avocado in California were each

Funding for this research was provided by the California State Water Resources Control Board in accordance with the California Proposition 50 ballot initiative of 2002 .

Special thanks to the cooperating nurseries and groves, and to University of California staff Kristine Gilbert, Dale Zurawski, Amy Storm, Christopher Martin, Maren Mochizuki, Shahram Ahmadian, Harold Ewing, Svetlana Bondarenko, and Frederick Ernst.

${ }^{1}$ Department of Environmental Sciences, University of California, Riverside, Geology Building 2208, Riverside, CA 92521

${ }^{2}$ University of California, Cooperative Extension, Ventura County, 669 County Square Drive, Suite 100, Ventura, CA 93003

${ }^{3}$ Department of Botany and Plant Sciences, University of California, Riverside, 4118 Batchelor Hall, Riverside, CA 92521

${ }^{4}$ Corresponding author. E-mail: jpnewman@ucdavis. edu. ranked in the top 20 agricultural commodities in terms of value for the state, with values of 2800,633 , 375 , and 342 million dollars, respectively, in 2006 (CDFA, 2007). Potential water quality concerns from agricultural production include runoff and leaching losses of nutrients, pesticides, and sediment (Ribaudo and Johansson, 2006). Agriculture is considered a leading source of impairment for U.S. rivers, lakes, and estuaries (Ribaudo and Johansson, 2006); however, the magnitude of impacts from citrus, avocado, and nursery operations on surface water and groundwater is not well documented.

Nursery RUNoff. Site-scale studies documenting runoff losses from production nurseries are few, and the results are not always consistent. A survey of container nurseries in the eastern United States found that runoff leaving nurseries exceeded 10 $\mathrm{mg} \cdot \mathrm{L}^{-1}$ nitrate-nitrogen $\left(\mathrm{NO}_{3}-\mathrm{N}\right)$, although some nurseries typically had low $\mathrm{NO}_{3}-\mathrm{N}$ concentrations (Yeager et al., 1993). Similarly, a survey of 11 production nurseries in southern California found that most nurseries had median $\mathrm{NO}_{3}-\mathrm{N}$ concentrations in runoff entering detention or recycling basins exceeding $10 \mathrm{mg} \cdot \mathrm{L}^{-1}$, but concentrations varied by nursery (Mangiafico et al., 2008).

Monitoring runoff from a 100 acre production nursery in southern California found bifenthrin concentrations up to $960 \mathrm{ng} \cdot \mathrm{L}^{-1}$, and cis- and transpermethrin up to 1450 and 270 ng. $L^{-1}$, respectively (Kabashima et al., 2004). These concentrations exceed acute lethal concentration $50\left(\mathrm{LC}_{50}\right)$ values for water flea (Ceriodaphnia dubia), a freshwater invertebrate that is commonly used as a water quality indicator, of $70 \mathrm{ng} \cdot \mathrm{L}^{-1}$ for bifenthrin, and $550 \mathrm{ng} \cdot \mathrm{L}^{-1}$ for permethrin (Mokry and Hoagland, 1990). A survey of 11 production nurseries in southern California found frequent detections of pyrethroid, organophosphate, and organochlorine insecticides in runoff entering detention or recycling basins (Mangiafico et al., 2008). Commonly detected pesticides included bifenthrin, fenopropathrin, permethrin, diazinon, chlorpyrifos, and DDT and its metabolites; however, the frequency of detection of these pesticides varied by site.

\begin{tabular}{llll}
\hline $\begin{array}{l}\text { Units } \\
\text { To convert U.S. to SI, } \\
\text { multiply by }\end{array}$ & U.S. unit & SI unit & $\begin{array}{l}\text { To convert SI to U.S., } \\
\text { multiply by }\end{array}$ \\
\hline 0.4047 & acre(s) & $\mathrm{ha}$ & 2.4711 \\
1 & $\mathrm{cbar}$ & $\mathrm{kPa}$ & 1 \\
29.5735 & $\mathrm{fl} \mathrm{oz}$ & $\mathrm{mL}$ & 0.0338 \\
0.3048 & $\mathrm{ft}$ & $\mathrm{m}$ & 3.2808 \\
3.7854 & $\mathrm{gal}$ & $\mathrm{L}$ & 0.2642 \\
2.54 & inch(es) & $\mathrm{cm}$ & 0.3937 \\
25.4 & inch(es) & $\mathrm{mm}$ & 0.0394 \\
1.1209 & lb/acre & $\mathrm{kg} \cdot \mathrm{ha}^{-1}$ & 0.8922 \\
1 & micron & $\mu \mathrm{m}$ & 1 \\
1 & $\mathrm{ppm}$ & $\mathrm{mg} \cdot \mathrm{L}^{-1}$ & 1 \\
1 & $\mathrm{ppt}$ & $\mathrm{ng} \cdot \mathrm{L}^{-1}$ & 1 \\
$\left({ }^{\circ} \mathrm{F}-32\right) \div 1.8$ & ${ }^{\circ} \mathrm{F}$ & ${ }^{\circ} \mathrm{C}$ & $\left(1.8 \times{ }^{\circ} \mathrm{C}\right)+32$
\end{tabular}


Grove RUNOFF. Nutrient concentrations in runoff from citrus groves are not extensively documented. One survey of drainage from 24 citrus sites in Florida found median concentrations in stormwater runoff of $0.04 \mathrm{mg} \cdot \mathrm{L}^{-1} \mathrm{NO}_{3}-\mathrm{N}+$ nitrite $\left(\mathrm{NO}_{2}\right)-\mathrm{N}, 0.06 \mathrm{mg} \cdot \mathrm{L}^{-1}$ ammonium $\left(\mathrm{NH}_{4}\right)-\mathrm{N}$, and $0.16 \mathrm{mg} \cdot \mathrm{L}^{-1}$ total phosphorus (P) (Graves et al., 2004). Other studies in Florida reported mean concentrations in stormwater runoff of 0.30 to $1.4 \mathrm{mg} \cdot \mathrm{L}^{-1}$ orthophosphorus $\left(\mathrm{PO}_{4}\right)-\mathrm{P}$ (He et al., 2006) and concentrations in the initial $2 \mathrm{~h}$ of storm runoff as high as $3 \mathrm{mg} \cdot \mathrm{L}^{-1} \mathrm{PO}_{4^{-}}$ $\mathrm{P}$ (Yu et al., 2006). Nutrient runoff from avocado groves has not been addressed in peer-reviewed studies.

Studies concerned with insecticide runoff from orchards have focused largely on diazinon and pyrethroid runoff from stone fruit (Prunus spp.) orchards in California's central valley. Of most concern has been runoff from precipitation events after dormant season application of pesticides. This is particularly a concern because, with California's Mediterranean climate, rainfall occurs primarily in the winter months when crop growth and biological activity may be limited. Runoff from these sites often had high diazinon concentrations or exhibited acute or chronic toxicity to invertebrates or fish (Holmes and de Vlaming, 2003; Joyce et al., 2004; Teh et al., 2005; Werner et al., 2004). Because pesticides and production practices employed in citrus and avocado groves are different from those of stone fruit orchards, it is not known if concerns about pesticide runoff from stone fruit orchards are applicable to citrus or avocado operations. Specifically, while diazinon concentrations were a focus in these studies, this insecticide is not currently used in citrus or avocado groves in California.

LEACHING. Leaching of nitrate and pesticides can contribute to groundwater contamination. The use of suction lysimeters is considered reliable for the estimation of contaminant leaching in sandy soils, although data from these devices may be misleading in structured or heterogeneous soils (Addiscott, 1996). Specifically, the small sampling volume from suction lysimeters may fail to represent the solute concentration of the soil profile (Addiscott, 1996). One study found that the radius of sampled soil volume with certain suction cup lysimeters in a sandy soil to be less than $0.2 \mathrm{~m}$, and that the region of influence would vary with sampling time and suction pressure (Wu et al., 1995). Additionally, the timing and frequency of sampling, particularly in relation to the occurrence of leaching events, may affect how accurately samples from suction lysimeters represent actual leached solute concentrations. It was found that suction lysimeters underestimated $\mathrm{NO}_{3}-\mathrm{N}$ leaching from vegetables grown in a sandy soil compared with values from drainage lysimeters for some treatments, even when the actual drainage flux was known (Zotarelli et al., 2007).

To determine leaching loads, solute concentrations from lysimeter samples can be coupled with water flux derived from hydrologic models. This approach may be most reasonable in a relatively uniform cropping system such as grassland (Addiscott, 1996) or turfgrass (Barton and Colmer, 2006). Modeling leaching volumes would become more difficult in more heterogeneous systems, for example in citrus groves, in which trees may be alternated with bare soil or cover crops, or in container nurseries where irrigation is applied to containers that may be sitting on compacted soil, weed cloth, or gravel. Given these considerations, soil water samples extracted with suction lysimeters from below the root zone may serve as indicators of solute concentrations in leachate, but should be interpreted cautiously, especially when not coupled with estimates of water drainage flux.

Nitrate-nitrogen concentrations of soil water taken with suction lysimeters from below the root zone of citrus trees in Florida have been reported as typically less than 10 $\mathrm{mg} \cdot \mathrm{L}^{-1}$, although some samples exceeded this level (Alva et al., 2006; He et al., 2000; Paramasivam et al., 2001). Low percentages of nitrate losses to leachate in drainage lysimeters has been reported for young citrus (Lea-Cox et al., 2001; Quiñones et al., 2007), although one study found mineral $\mathrm{N}$ losses between $35 \%$ and $53 \%$ in leachate $0.76 \mathrm{~m}$ below the soil surface for young citrus (Boman and Battikhi, 2007).

Leaching losses through soils below container nurseries have rarely been investigated. One study in Connecticut found mean annual flowweighted concentrations of $\mathrm{NO}_{3}-\mathrm{N}$ below container-grown rhododendron (Rhododendron spp.) of 7.2 and $12.7 \mathrm{mg} \cdot \mathrm{L}^{-1}$, depending on irrigation practices (Colangelo and Brand, 2001). Other studies have reported an accumulation of $\mathrm{NO}_{3}-\mathrm{N}$ in soil under woody and herbaceous container-grown crops (Brand et al., 1993; McAvoy, 1994; McAvoy et al., 1992). This increase in soil $\mathrm{NO}_{3}-\mathrm{N}$ occurred particularly in the top $30 \mathrm{~cm}$ of the soil profile, although increases in soil $\mathrm{NO}_{3}-\mathrm{N}$ were found to a depth of $90 \mathrm{~cm}$.

Purpose. This study was conducted to document nutrient and pesticide concentrations in stormwater runoff from nursery, citrus, and avocado production sites, and to assess the potential for groundwater contamination with nutrients from these sites by measuring nutrient concentrations in the soil water below the root zone of these crops.

\section{Materials and methods}

COOPERATING SITE DESCRIPTIONS. Stormwater runoff and soil water samples were collected from 10 citrus or avocado groves and seven production nursery sites in Ventura County, CA, between Aug. 2006 and Feb. 2008. All grove sites used microsprinkler irrigation exclusively. At these grove sites, nitrogen fertilizers were injected into irrigation water, applied to the soil as granules, or applied to leaves. The most common nitrogen sources were soluble chemical sources, with urea as the most commonly reported, and organic sources. For grove sites where data were available, $\mathrm{N}$ fertilizer application rates ranged from 20 to $57 \mathrm{lb} /$ acre per year. Phosphorus fertilizers were injected into irrigation water or applied to leaves, with phosphorus acid being the most common source. For sites where data were available, $P$ fertilizer application rates ranged from 0 to 26 $\mathrm{lb} /$ acre per year.

Nursery sites used low-volume irrigation, overhead sprinklers, or handwatering. Applied fertilizers at these sites included soluble chemical, slow release, and organic sources. For nursery sites where data were available, fertilizer application rates ranged from 0 to $580 \mathrm{lb} /$ acre $\mathrm{N}$ per year and 0 to $260 \mathrm{lb} /$ acre $P$ per year. 
Pesticide use by cooperators was determined in interviews with the cooperators, and was confirmed with county pesticide use records for 2006 (Ventura County Agricultural Commissioner, 2008), which was the most recent data available at the time of writing.

StOrMwater RUNOFF. Stormwater surface runoff from precipitation events was collected as manual grab samples. In most cases, sampled water was leaving the site property, although in some cases, sampled runoff was leaving a production area within the site. Among the selected sites, only two sites produced observable runoff during irrigation events, and they produced this runoff daily. Runoff from irrigation events was not included in this study so as not to bias pooled data by over-representing these sites because many more samples would have been obtained for irrigation runoff than storm runoff.

Due to California's Mediterranean climate, most rain occurred in the winter, typically from October to April (Fig. 1). Weather reports from across the county were used to determine which sites in the county were receiving rainfall that might be causing runoff. During the study period, using Santa Paula, CA, as a representative area, there were 11 storm events producing at least $0.5 \mathrm{~cm}$ of precipitation. Runoff sampling was attempted for 10 of these events, with runoff observed and collected for six of these events. The one missed rain event occurred in Dec. 2006 and lasted for only about $8 \mathrm{~h}$ on a Sunday night, when field staff typically are not deployed. Multiple runoff samples for a single storm were taken on different days, when available, for storms lasting for more than 1 day. Collection frequency varied by site depending on whether precipitation events produced observable runoff for a particular site. Storms for which there were successful runoff samples occurred in Feb. 2007, Apr. 2007, Dec. 2007, Jan. 2008, and Feb. 2008. With this methodology, collected samples did not have a set timing relative to the start of precipitation or the beginning of runoff.

Lysimeter samples. Porous ceramic cup suction lysimeters with PVC bodies and porous cups of 2.4 $\mathrm{cm}$ in diameter and $6.2 \mathrm{~cm}$ in height (model SSAT; Irrometer, Riverside,

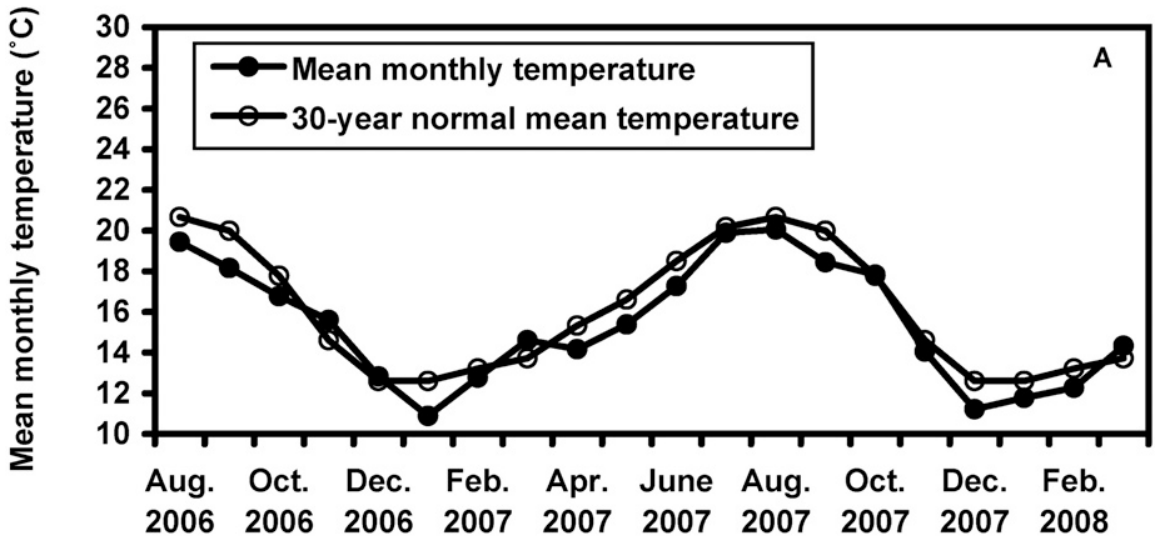

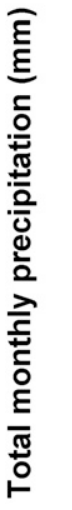

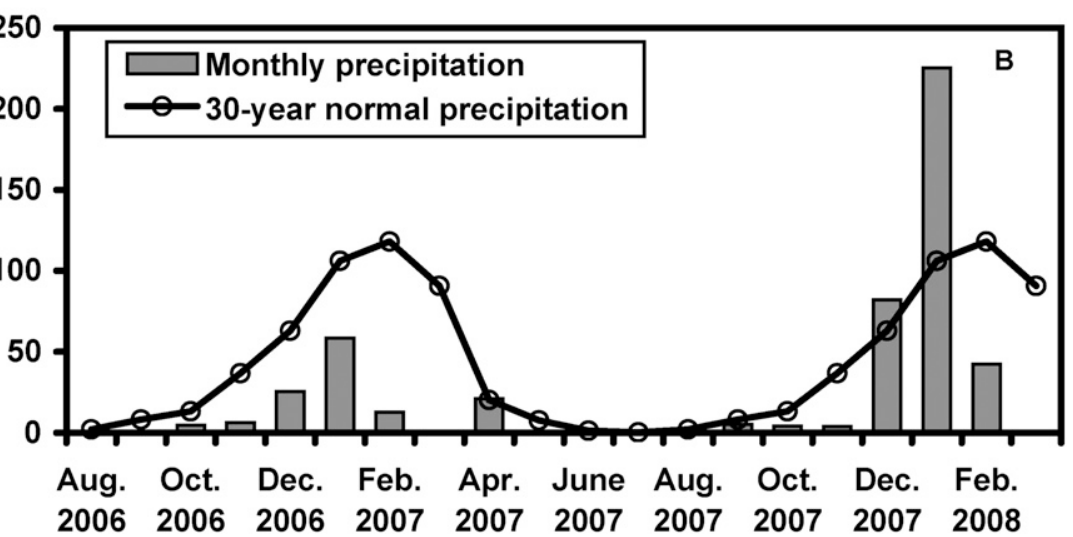

Fig. 1. Mean monthly air temperature (A) and monthly precipitation (B) for Santa Paula, CA, during the study period. Mean monthly temperatures were $0.7^{\circ} \mathrm{C}$ $\left(1.3^{\circ} \mathrm{F}\right)$ below normal, and precipitation was $412 \mathrm{~mm}$, or $46 \%$, below normal. Data from California Irrigation Management Information System (CIMIS) station 198, National Oceanic and Atmospheric Administration (NOAA) cooperative station $047957 ;\left(1.8 \times{ }^{\circ} \mathrm{C}\right)+32={ }^{\circ} \mathrm{F}, 1 \mathrm{~mm}=0.0394$ inch.

CA) were installed at $30 \mathrm{~cm}$ below the soil surface for nursery sites, at $90 \mathrm{~cm}$ for avocado sites, and at $120 \mathrm{~cm}$ for citrus sites. In each case, these depths were below the nominal majority of crop roots. For citrus and avocado sites, lysimeters were installed between a tree and an adjacent irrigation emitter. The ceramic end of the cup was soaked in water before installation. During installation, the installation hole was backfilled with moist soil or soil slurry to ensure good contact between the ceramic cup and surrounding soil and to prevent sampling seepage directly from the soil surface. During sampling, lysimeters were evacuated to $60 \mathrm{kPa}$ of suction, and allowed to draw soil water for $24 \mathrm{~h}$. Four or more lysimeters were installed at each sampling site, and samples were composited for the site. Samples from groves with citrus and avocado areas were kept separated for citrus and avocado subsites. Soil water was typically sampled twice per month at each site, although sampling frequency varied across sites and time depending on site conditions. Because soil water samples were collected in PVC tubes, these samples were not analyzed for pesticides due to a concern for adsorption losses.

SAMPLE PREPARATION AND ANALYSIS. Samples for nutrient analysis were collected in $250-\mathrm{mL}$ polyethylene bottles (Nalgene Labware; Nalge Nunc International, Rochester, NY) and samples for pesticide analysis were collected in 1-L amber glass jars (I-chem 300 series; Chase Scientific Glass, Rockwood, TN). Samples were stored at $4{ }^{\circ} \mathrm{C}$ until analysis. Samples for nutrient analysis were filtered through polycarbonate membranes with a $0.4-\mu \mathrm{m}$ pore size (Millipore, Billerica, MA). Concentrations for $\mathrm{NO}_{2}-\mathrm{N}+\mathrm{NO}_{3}-\mathrm{N}$ [U.S. Environmental Protection Agency (USEPA) method 353.2 (USEPA, 1993)], $\mathrm{NH}_{4}-\mathrm{N}$ [USEPA method 350.1 (USEPA, 1979)], and $\mathrm{PO}_{4}-\mathrm{P}$ 
[USEPA method 365.2 (USEPA, 1993)] were determined with a segmented flow analyzer (Astoria model; Astoria-Pacific, Clackamas, OR).

Pesticide analysis was conducted using unfiltered whole water samples, which included analytes associated with sediment particles or organic matter. Samples were extracted with $50 \mathrm{~mL}$ of methylene chloride three times in 2-L separatory funnels. Sample bottles were rinsed with methylene chloride to recover any adsorbed analyte. The extract was passed through $40 \mathrm{~g}$ of anhydrous sodium sulfate, concentrated to dryness, and reconstituted in $1 \mathrm{~mL}$ of $\mathrm{n}$-hexane. Samples were analyzed by gas chromatography coupled with a microelectron capture detector and dual columns [DB-5MS, $30 \mathrm{~m} \times 0.25$ $\mathrm{mm} \times 0.32 \mu \mathrm{m}$, and DB-1701, $30 \mathrm{~m}$ $\times 0.25 \mathrm{~mm} \times 0.25 \mu \mathrm{m}$ (model 6890; Agilent, Santa Clara, CA)] for four classes of pesticides: pyrethroids, organophosphates, organochlorines, and carbamates, following methods consistent with USEPA methods 3510C, 8141, and 8081 (USEPA, 1997).

Samples for turbidity analysis were collected in polyethylene bottles, transported to the laboratory, and analyzed with a portable turbidimeter (model 2100P; Hach, Loveland, CO). Results were expressed in nephelometric turbidity units (NTU), and an average of three readings for each sample was recorded. The maximum reported value for this instrument is $1000 \mathrm{NTU}$. When the instrument reported a value of $1000 \mathrm{NTU}$, this value was recorded, even though actual sample turbidity may have exceeded this value.

Statistical analysis. Nutrient concentrations below nominal detection limits were replaced by one-half the detection limit (USEPA, 2000b). Pesticide concentrations below nominal detection limits were considered "not detected." Because there were few runoff samples at each site (Table 1), no summary statistics of runoff results for individual sites were considered. Results from grove and nursery sites were pooled, and linear regression analyses were applied to determine if nutrient concentrations in runoff or soil water were related to $\mathrm{N}$ or $\mathrm{P}$ fertilizer application rates across sites. A linear regression analysis was applied to determine if the

Table 1. Production area, major products, and number of samples for 10 citrus or avocado groves and seven production nurseries in Ventura County, CA.

\begin{tabular}{|c|c|c|c|c|c|}
\hline Site & $\begin{array}{c}\text { Site } \\
\text { category }\end{array}$ & $\begin{array}{c}\text { Production } \\
\text { area } \\
(\text { acres })^{\mathrm{z}}\end{array}$ & $\begin{array}{c}\text { Major products } \\
\text { in studied } \\
\text { area }^{\mathrm{y}}\end{array}$ & $\begin{array}{l}\text { Stormwater } \\
\text { runoff } \\
\text { samples } \\
\text { (no.) }\end{array}$ & $\begin{array}{c}\text { Soil water } \\
\text { lysimeter } \\
\text { samples } \\
\text { (no.) }\end{array}$ \\
\hline A & Grove & 14 & Avocado & 1 & 7 \\
\hline B & Grove & 17 & Citrus and avocado & 1 & 13 \\
\hline $\mathrm{C}$ & Grove & 9 & $\begin{array}{l}\text { Citrus, avocado, and } \\
\text { other tree fruit }\end{array}$ & 1 & $0^{\mathrm{x}}$ \\
\hline $\mathrm{D}$ & Grove & 11 & Avocado and citrus & $0^{\mathrm{w}}$ & 12 \\
\hline $\mathrm{E}$ & Grove & 25 & Citrus and avocado & 2 & 9 \\
\hline $\mathrm{F}$ & Grove & 42 & Avocado & $0^{\mathrm{w}}$ & 13 \\
\hline G & Grove & 22 & Avocado & 2 & 14 \\
\hline $\mathrm{H}$ & Grove & 35 & Avocado & 3 & 13 \\
\hline I & Grove & 248 & Citrus and avocado & 3 & 7 \\
\hline $\mathrm{J}$ & Grove & 20 & Avocado & 2 & 9 \\
\hline K & Nursery & 37 & Palms in containers & 1 & 16 \\
\hline $\mathrm{L}$ & Nursery & 2 & Lavender in ground & 3 & $0^{\mathrm{v}}$ \\
\hline M & Nursery & 8 & Groundcovers in containers & 2 & $0^{\mathrm{u}}$ \\
\hline $\mathrm{N}$ & Nursery & 2 & Ornamentals in containers & $0^{\mathrm{w}}$ & 8 \\
\hline $\mathrm{O}$ & Nursery & 30 & Ornamentals in ground & 4 & 10 \\
\hline $\mathrm{P}$ & Nursery & 7 & $\begin{array}{l}\text { Ornamentals in containers } \\
\text { and celery propagation }\end{array}$ & 1 & $0^{\mathrm{u}}$ \\
\hline Q & Nursery & 40 & Ornamentals in containers & 1 & 19 \\
\hline Total & & & & 27 & 150 \\
\hline
\end{tabular}

${ }^{2} 1$ acre $=0.4047$ hectares.

yAvocado (Persea americana), citrus (Citrus spp.), palm (Arecaceae), lavender (Lavandula spp.), and celery (Apium graveolens).

${ }^{x}$ No lysimeter samples were collected in the avocado or citrus production areas of this site.

"Runoff from precipitation was not observed for this site during the study period.

"Lysimeter sampling was not successful at this site, presumably because the soil was too dry during sampling attempts.

"No lysimeter sampling was attempted at this site.

concentrations of each detected pesticide were linearly related to sample turbidity, and chi-square and $t$ test analyses were used to determine if pesticide detections or concentrations in runoff were related to pesticide use. These analyses were performed in SAS (version 9.1.3; SAS Institute, Cary, NC) using the REG, FREQ, and TTEST procedures. Percentiles were determined in SAS using an empirical distribution with averaging method with the UNIVARIATE procedure.

\section{Results and discussion}

Precipitation AND Stormwater RUNOFF. Up to four surface stormwater runoff samples were collected for each site during the study period (Table 1 ). While precipitation amounts probably varied across sites, precipitation for a representative area was $46 \%$ below normal during the study period (Fig. 1), which may explain the infrequency of observed runoff in some cases. At some sites, heavily mulched areas, sandy soils, or flat topography may also have limited the frequency of observed precipitation runoff. Stormwater runoff may be more frequent when rainfall is greater or more intense or when sites are sloped or have bare compacted soils.

Nutrients IN STORMWATER RUNOFF. Nutrient concentrations in stormwater runoff were similar between grove and nursery sites, with the exception of $\mathrm{PO}_{4}-\mathrm{P}$, for which the median concentration for nurseries was close to that of the maximum concentration for groves (Fig. 2). $\mathrm{NO}_{3}-\mathrm{N}+\mathrm{NO}_{2}-\mathrm{N}$ concentrations in runoff ranged from 0.07 to 31.1 $\mathrm{mg} \cdot \mathrm{L}^{-1}$, with medians for groves and nurseries of 4.2 and $5.7 \mathrm{mg} \cdot \mathrm{L}^{-1}$, respectively (Fig. 2A). These median values were below the USEPA recommended water quality criterion (RWQC) for human health for $\mathrm{NO}_{3}-\mathrm{N}$ of $10 \mathrm{mg} \cdot \mathrm{L}^{-1}$ (USEPA, 2006), although some samples exceeded this criterion. This criterion is a drinking water standard, and may not reflect a $\mathrm{NO}_{3}-\mathrm{N}$ threshold of environmental concern for surface waters. Median $\mathrm{PO}_{4}-\mathrm{P}$ concentrations for runoff from groves and 


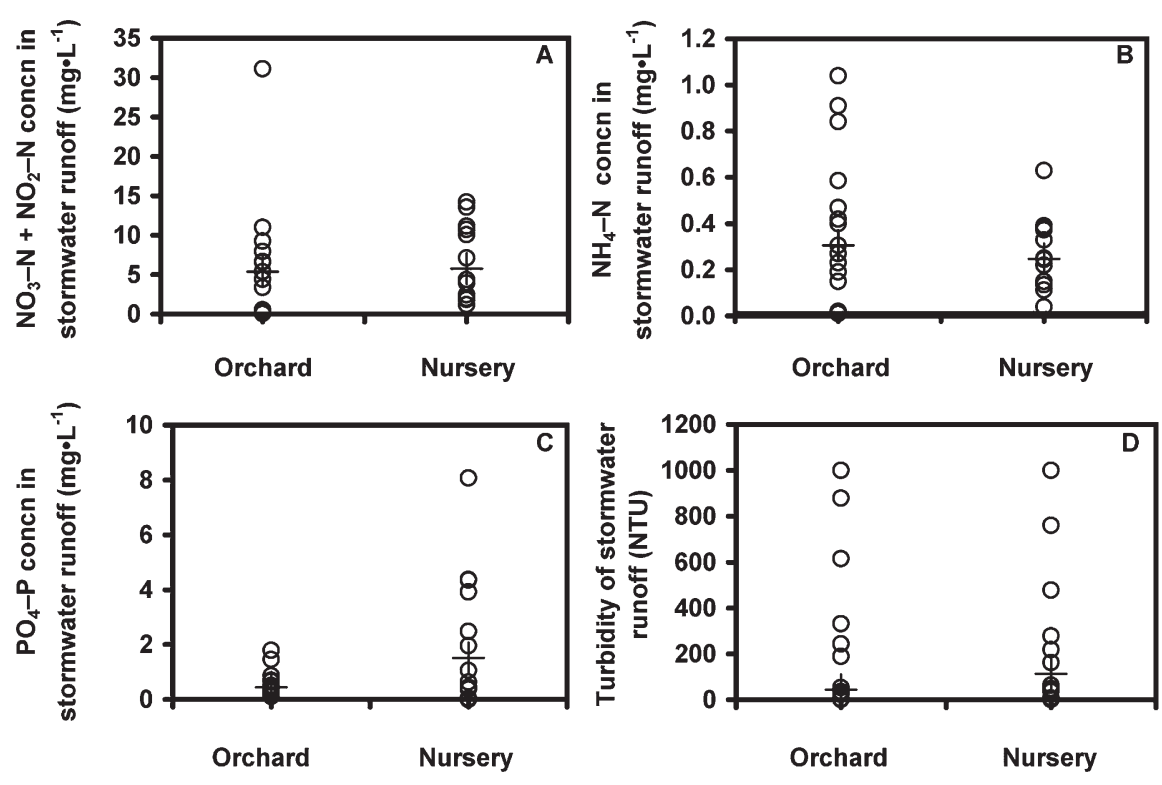

Site category

Fig. 2. Nutrient concentrations and turbidity of stormwater runoff from eight citrus and avocado groves and six production nurseries in Ventura County, CA. The scale of the $y$-axes vary among plots. Circles represent individual observations, and crosses represent median values. Median concentrations for grove and nursery sites for nitrate-nitrite-nitrogen $\left(\mathrm{NO}_{3}-\mathrm{N}+\mathrm{NO}_{2}-\mathrm{N}\right)$ were 4.2 and $5.7 \mathrm{mg} \cdot \mathrm{L}^{-1}$, respectively (A); 0.3 and $0.3 \mathrm{mg} \cdot \mathrm{L}^{-1}$ for ammonium-nitrogen $\left(\mathrm{NH}_{4}-\mathrm{N}\right)(\mathrm{B}) ; 0.4$ and $1.5 \mathrm{mg} \cdot \mathrm{L}^{-1}$ for orthophosphate $\left(\mathrm{PO}_{4}-\mathrm{P}\right)(\mathrm{C})$; and 44 and 114 nephelometric turbidity units (NTU) for turbidity (D). Number of samples $=15$ for grove sites and 12 for nursery sites; $1 \mathrm{mg} \cdot \mathrm{L}^{-1}=1 \mathrm{ppm}$.

nurseries were 0.4 and $1.5 \mathrm{mg} \cdot \mathrm{L}^{-1}$, respectively, with concentrations ranging from below the detection limit of 0.01 to $8.1 \mathrm{mg} \cdot \mathrm{L}^{-1}$ (Fig. 2C). These median values exceeded the USEPA aggregate reference conditions (ARC) for streams for the ecoregion of $0.022 \mathrm{mg} \cdot \mathrm{L}^{-1}$ for total P. No sample exceeded the maximum for streams of the ecoregion of 12.8 $\mathrm{mg} \cdot \mathrm{L}^{-1}$ (USEPA, 2000a), however. Turbidity in runoff was high compared with the USEPA ARC for the region of $1.8 \mathrm{NTU}$, and samples commonly exceeded the maximum level of 158 NTU for streams of the region (Fig. 2D; USEPA, 2000a).

Stormwater runoff $\mathrm{NO}_{3}-\mathrm{N}+$ $\mathrm{NO}_{2}-\mathrm{N}$ concentrations from nursery sites were generally lower than $\mathrm{NO}_{3}-$ $\mathrm{N}$ concentrations found in a previous survey of production nurseries, where the median concentration in stormwater runoff was $15.6 \mathrm{mg} \cdot \mathrm{L}^{-1}$ (Mangiafico et al., 2008), although they were similar to those found in a survey of nurseries that used controlledrelease fertilizers in the eastern United States in which the mean $\mathrm{NO}_{3}-\mathrm{N}$ concentration was $8 \mathrm{mg} \cdot \mathrm{L}^{-1}$ and the maximum was $33 \mathrm{mg} \cdot \mathrm{L}^{-1}$ (Yeager et al., 1993). Nutrient concentrations for runoff from grove sites were generally higher than reported for one survey of citrus sites in which the median $\mathrm{NO}_{3}-\mathrm{N}+\mathrm{NO}_{2}-\mathrm{N}$ concentration was $0.04 \mathrm{mg} \cdot \mathrm{L}^{-1}$ and the median total $\mathrm{P}$ concentration was $0.16 \mathrm{mg} \cdot \mathrm{L}^{-1}$ (Graves et al., 2004), but were similar to $\mathrm{PO}_{4}-\mathrm{P}$ values reported by other studies for citrus, where $\mathrm{PO}_{4}-\mathrm{P}$ concentrations in runoff ranged as high as $3 \mathrm{mg} \cdot \mathrm{L}^{-1}$ ( $\mathrm{He}$ et al., 2006; Yu et al., 2006). Turbidity values for grove runoff tended to greatly exceed those reported from a survey of citrus sites in which maximum reported turbidity was 17 NTU (Graves et al., 2004). No relationship $(P \geq 0.05)$ was found between $\mathrm{NO}_{3}-\mathrm{N}+\mathrm{NO}_{2}-\mathrm{N}, \mathrm{NH}_{4}$ $\mathrm{N}$, or $\mathrm{PO}_{4}-\mathrm{P}$ concentrations in runoff and $\mathrm{N}$ or $\mathrm{P}$ application rates across sites (data not shown).

Pesticides in STORMWATER RUNOFF. Pesticides frequently detected in stormwater runoff from groves and nurseries included compounds from the pyrethroid, organophosphate, and organochlorine classes (Table
2). Bifenthrin was frequently detected at grove and nursery sites, but maximum concentrations in runoff were below reported acute $\mathrm{LC}_{50}$ of 70 $n g \cdot \mathrm{L}^{-1}$ for water flea (Mokry and Hoagland, 1990). Likewise, maximum concentrations of permethrin in nursery runoff were below reported acute $\mathrm{LC}_{50}$ of $550 \mathrm{ng} \cdot \mathrm{L}^{-1}$ for water flea (Mokry and Hoagland, 1990). Diazinon was detected in $21 \%$ and $33 \%$ of runoff samples for groves and nurseries respectively (Table 2 ), but maximum detected concentrations did not exceed the USEPA freshwater chronic criterion of $170 \mathrm{ng} \cdot \mathrm{L}^{-1}$ (USEPA 2006) or a more stringent California chronic criterion for freshwater of $50 \mathrm{ng} \cdot \mathrm{L}^{-1}$ (Siepmann and Finlayson, 2002). In contrast to this, concentrations of chlorpyrifos occasionally exceeded the USEPA freshwater acute criterion of $83 \mathrm{ng} \cdot \mathrm{L}^{-1}$ (Nowell and Resek, 1994), with about $25 \%$ of samples for groves and nurseries exceeding a more stringent chronic criterion of $14 \mathrm{ng} \cdot \mathrm{L}^{-1}$ for California (Siepmann and Finlayson, 2002). When detected, chlordane, DDT, DDD, and DDE often exceeded chronic criteria for freshwater, which are $4 \mathrm{ng} \cdot \mathrm{L}^{-1}$ for chlordane and $1 \mathrm{ng} \cdot \mathrm{L}^{-1}$ for the sum of DDT and its metabolites (Nowell and Resek, 1994; USEPA 2006). With regard to nursery runoff, fewer pesticides in the pyrethroid and organochlorine classes were detected in this study than in a previous survey (Mangiafico et al., 2008), and maximum concentrations were considerably lower than in other studies (Kabashima et al., 2004; Mangiafico et al., 2008). Although fewer organochlorines were detected in this study, concentrations were similar to those in a survey of 11 production nurseries (Mangiafico et al., 2008). In the present study, most of the detected pesticides-chlorpyrifos, bifenthrin, permethrin, DDT and its metabolites, and chlordane-have high affinities for sediments (Bondarenko and Gan, 2004; Gan et al., 2005; U.S. Health and Human Services, 1994, 2002). When detected, chlorpyrifos concentrations were linearly related to sample turbidity $\left(P=0.0025, r^{2}=\right.$ 0.49 , data not shown). These observations suggest that the retention of sediment on site may be an effective method of mitigating pesticide runoff for these operations. The 
Table 2. Frequencies of detections and concentrations for detected pesticides in stormwater runoff from eight citrus or avocado groves and six production nurseries in Ventura County, CA.

\begin{tabular}{|c|c|c|c|c|c|c|c|}
\hline & $\begin{array}{c}\text { Samples } \\
\text { (no.) }\end{array}$ & $\begin{array}{c}\text { Detections } \\
\text { (no.) }\end{array}$ & $\begin{array}{c}\text { Detections } \\
(\%)\end{array}$ & $\begin{array}{c}\text { 50th } \\
\text { percentile } \\
\left(\mathrm{ng} \cdot \mathrm{L}^{-1}\right)^{\mathrm{z}}\end{array}$ & $\begin{array}{c}75 \text { th } \\
\text { percentile } \\
\left(\mathrm{ng} \cdot \mathrm{L}^{-1}\right)\end{array}$ & $\begin{array}{c}\text { 90th } \\
\text { percentile } \\
\left(\mathrm{ng} \cdot \mathrm{L}^{-1}\right)\end{array}$ & $\begin{array}{c}\text { 100th } \\
\text { percentile } \\
\left(\mathrm{ng} \cdot \mathrm{L}^{-1}\right)\end{array}$ \\
\hline & & & & Grove & & & \\
\hline \multicolumn{8}{|l|}{ Pyrethroids ${ }^{\mathrm{y}}$} \\
\hline Bifenthrin & 14 & 6 & 43 & $\mathrm{n} / \mathrm{d}^{\mathrm{x}}$ & 13 & 21 & 24 \\
\hline \multicolumn{8}{|l|}{ Organophosphates ${ }^{w}$} \\
\hline \multicolumn{8}{|l|}{ Organochlorines $^{v}$} \\
\hline trans-Chlordane & 14 & 2 & 14 & $\mathrm{n} / \mathrm{d}$ & $\mathrm{n} / \mathrm{d}$ & 15 & 154 \\
\hline$p, p^{\prime}$-DDT (dichloro-diphenyl-trichloroethane) & 14 & 6 & 43 & $\mathrm{n} / \mathrm{d}$ & 7 & 34 & 64 \\
\hline$p, p^{\prime}$-DDD (dichloro-diphenyl-dichloroethane) & 14 & 4 & 29 & $\mathrm{n} / \mathrm{d}$ & 2 & 6 & 26 \\
\hline$p, p^{\prime}$-DDE (dichloro-diphenyl-dichloroethylene) & 14 & 6 & 43 & $\mathrm{n} / \mathrm{d}$ & 9 & 16 & 46 \\
\hline trans-Permethrin & 12 & 1 & 8 & $\mathrm{n} / \mathrm{d}$ & $\mathrm{n} / \mathrm{d}$ & $\mathrm{n} / \mathrm{d}$ & 10 \\
\hline \multicolumn{8}{|l|}{ Organophosphates } \\
\hline Diazinon & 12 & 4 & 33 & $\mathrm{n} / \mathrm{d}$ & 9 & 14 & 17 \\
\hline Chlorpyrifos & 12 & 7 & 58 & 3 & 11 & 38 & 115 \\
\hline \multicolumn{8}{|l|}{ Organochlorines } \\
\hline trans-Chlordane & 12 & 5 & 42 & $\mathrm{n} / \mathrm{d}$ & 6 & 7 & 12 \\
\hline Endosulfan sulfate & 12 & 1 & 8 & $\mathrm{n} / \mathrm{d}$ & $\mathrm{n} / \mathrm{d}$ & $\mathrm{n} / \mathrm{d}$ & 95 \\
\hline$p, p^{\prime}$-DDT (dichloro-diphenyl-trichloroethane) & 12 & 7 & 58 & 1 & 6 & 103 & 221 \\
\hline$p, p^{\prime}$-DDD (dichloro-diphenyl-dichloroethane) & 12 & 4 & 33 & $\mathrm{n} / \mathrm{d}$ & 2 & 25 & 96 \\
\hline$p, p^{\prime}$-DDE (dichloro-diphenyl-dichloroethylene) & 12 & 8 & 67 & 3 & 12 & 136 & 303 \\
\hline
\end{tabular}

${ }^{\mathrm{z}} \mathrm{l} \mathrm{ng} \cdot \mathrm{L}^{-1}=1 \mathrm{ppt}$

yetection limits for pyrethroid pesticides were: $1.5 \mathrm{ng} \cdot \mathrm{L}^{-1}$ bifenthrin, $6.9 \mathrm{ng} \cdot \mathrm{L}^{-1}$ cis-permethrin, and $8.1 \mathrm{ng} \cdot \mathrm{L}^{-1}$ transpermethrin.

${ }^{\mathrm{x}} \mathrm{n} / \mathrm{d}=$ not detected

"Detection limits for diazinon and chlorpyrifos were 5 and $1 \mathrm{ng} \cdot \mathrm{L}^{-1}$, respectively.

v Detection limits for organochlorine pesticides were: $1 \mathrm{ng} \cdot \mathrm{L}^{-1}$ transchlordane, $5 \mathrm{ng} \cdot \mathrm{L}^{-1}$ endosulfan sulfate, and $1 \mathrm{ng} \cdot \mathrm{L}^{-1} \mathrm{DDT}$, DDD, and DDE.

concentration of no other pesticide was significantly related to sample turbidity $(P \geq 0.05)$. Analysis methods did not include certain pesticides commonly used in these nursery and grove sites. These included abamectin and simazine in groves, and pendimethalin, acephate, and malathion in nurseries, all of which may be of concern in runoff.

In general, there was no clear correlation between reported pesticide use and pesticide detections in stormwater runoff. For example, while no cooperator reported using bifenthrin or diazinon, detections of these pesticides in runoff were frequent, though concentrations of these compounds in runoff were low (Table 2). This suggests the possibility that these pesticides made their way onto cooperator sites by drift from neighboring sites or as residual from past use. Similarly, some legacy organochlorine pesticides, such as DDT and its metabolites, were frequently detected in runoff (Table
2), although no cooperator reported using them. Most probably, these compounds were from historical use and entered the runoff stream with eroded sediment particles. Chlorpyrifos was used at three cooperating sites and was detected in $59 \%$ of stormwater samples. No relationship $(P \geq 0.05)$ was found relating the detection or concentration of chlorpyrifos with whether that pesticide was used at the site. However, the highest concentrations in runoff were found at sites that reported using chlorpyrifos. These observations suggest that pesticide runoff could be reduced at these sites by reducing the use of certain pesticides, such as chlorpyrifos, and by preventing soil erosion and retaining onsite eroded sediments that could contain residual pesticides.

Nutrients IN SOIL WATER. Soil water samples from below the crop root zone were collected from nine grove sites and four nursery sites (Table 1). Not all sites produced water samples for all sampling attempts, presumably because the soil was too dry for lysimeters to draw soil water at $60 \mathrm{kPa}$. In general, nutrient concentrations in soil water were similar to nutrient concentrations in stormwater runoff (Fig. 3 and Fig. 2 , respectively), although maximum values were notably higher in soil water for $\mathrm{NO}_{3}-\mathrm{N}+\mathrm{NO}_{2}-\mathrm{N}$, and $\mathrm{NH}_{4}-\mathrm{N}$. Median $\mathrm{NO}_{3}-\mathrm{N}+\mathrm{NO}_{2}-\mathrm{N}$ for avocado and citrus subsites were 3.4 and $8.2 \mathrm{mg} \cdot \mathrm{L}^{-1}$, respectively, which were below the USEPA RWQC for human health for $\mathrm{NO}_{3}-$ $\mathrm{N}$ of $10 \mathrm{mg} \cdot \mathrm{L}^{-1}$ (USEPA, 2006). However, $\approx 25 \%$ of samples for these subsites exceeded this benchmark (Fig. 3A). Median $\mathrm{NO}_{3}-\mathrm{N}+\mathrm{NO}_{2}-$ $\mathrm{N}$ of soil water for nursery sites was $20.2 \mathrm{mg} \cdot \mathrm{L}^{-1}$ (Fig. 3A), which was in excess of the USEPA RWQC. These results suggest that potential groundwater contamination with nutrients from citrus, avocado, and nursery sites may be as much of a concern as 

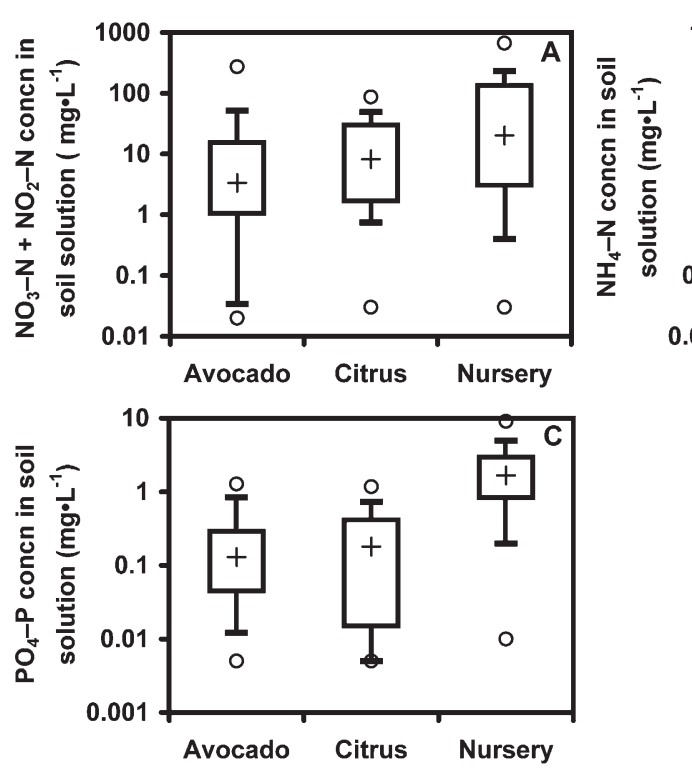

Avocar

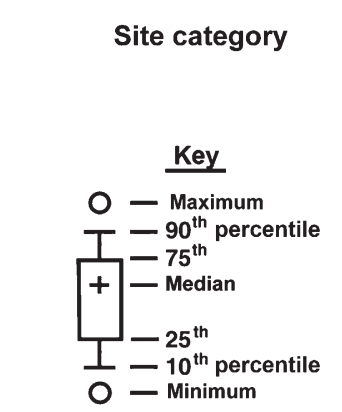

Site category

Fig. 3. Boxplots of nutrient concentrations in soil solution below the root zone from nine avocado sites, four citrus sites, and four production nurseries in Ventura County, CA. The $y$-axes are log scale and vary among plots. Median concentrations for avocado, citrus, and nursery sites for nitrate-nitrite-nitrogen $\left(\mathrm{NO}_{3}-\mathrm{N}+\mathrm{NO}_{2}-\right.$ $\mathrm{N}$ ) were $3.4,8.2$, and $20.2 \mathrm{mg} \cdot \mathrm{L}^{-1}$, respectively $(\mathrm{A}) ; 0.1,0.08$, and $0.1 \mathrm{mg} \cdot \mathrm{L}^{-1}$ for ammonium-nitrogen $\left(\mathrm{NH}_{4}-\mathrm{N}\right)(\mathrm{B}) ; 0.1,0.2$, and $1.7 \mathrm{mg} \cdot \mathrm{L}^{-1}$ for orthophosphate $\left(\mathrm{PO}_{4}-\mathrm{P}\right)(\mathrm{C})$. Total number of observations per plot is 150 (63 avocado, 34 citrus, 53 nursery); $1 \mathrm{mg} \cdot \mathrm{L}^{-1}=1 \mathrm{ppm}$.

nutrient runoff for these operations. Leaching losses will be a concern, especially on sites where sandy or well-structured soils or flat topography promote a high leaching water flux. Because lysimeters were installed just below the majority of roots of soil-grown crops and were left under suction for $24 \mathrm{~h}$, concentrations in lysimeter samples may have been influenced by soil water in the crop root zone for sites with soil-grown crops.

$\mathrm{NO}_{3}-\mathrm{N}+\mathrm{NO}_{2}-\mathrm{N}$ concentrations in soil water were linearly related to $\mathrm{N}$ application rate across sites $(P<$ $\left.0.0001 ; r^{2}=0.50\right)$, and $\mathrm{PO}_{4}-\mathrm{P}$ concentrations in soil water were linearly related to $\mathrm{P}$ application rate across sites $\left(P<0.0001 ; r^{2}=0.49\right)$ (data not shown). These $r^{2}$ values suggest that fertilizer application rates determine to a considerable extent nutrient concentrations in soil water. This suggests that care in making nutrient management decisions and reducing fertilizer application rates are important for reducing the threat of nutrient leaching losses. Such a relationship was not found for $\mathrm{NH}_{4}-\mathrm{N}$ soil water concentrations $(P \geq 0.05)$.

\section{Conclusions}

Constituents in stormwater runoff from nursery and grove sites that exceeded surface water quality benchmarks included turbidity, chlorpyrifos, and some organochlorine pesticides. These pesticides, along with the detected pyrethroid pesticides, are preferentially associated with sediment particles in runoff. Chlorpyrifos concentrations in runoff were linearly related to sample turbidity. These observations suggest that pesticide runoff could be reduced at these sites by reducing the use of certain pesticides, such as chlorpyrifos, and by preventing soil erosion and retaining onsite eroded sediments that could contain residual pesticides. Nitratenitrite-nitrogen and $\mathrm{PO}_{4}-\mathrm{P}$ concentrations also exceeded benchmarks for some runoff samples. For nursery stormwater runoff, fewer pesticides were detected in this study than in previous studies, and nutrient concentrations were generally lower than were found in a survey of production nurseries in the same region. Nutrient concentrations in soil water below crop root zones were generally similar to nutrient concentrations in runoff. This suggests that potential groundwater contamination through leaching from citrus, avocado, and nursery sites may be as much of a concern as nutrient runoff in stormwater from these operations, particularly on sites with sandy or structured soil texture or flat topography. Nutrient concentrations in soil water were linearly related to $\mathrm{N}$ and $\mathrm{P}$ fertilizer application rates across sites, suggesting that proper nutrient management is important in reducing potential groundwater contamination at these operations.

\section{Literature cited}

Addiscott, T.M. 1996. Measuring and modelling nitrogen leaching: Parallel problems. Plant Soil 181:1-6.

Alva, A.K., S. Parmamasivam, A. Fares, T.A. Obreza, and A.W. Schumann. 2006. Nitrogen best management practice for citrus trees II: Nitrogen fate, transport, and components of $\mathrm{N}$ budget. Scientia Hort. 109:223-233.

Barton, L. and T.D. Colmer. 2006. Irrigation and fertiliser strategies for minimizing nitrogen leaching from turfgrass. Agr. Water Mgt. 80:160-175.

Boman, B.J. and A.M. Battikhi. 2007. Growth, evapotranspiration, and nitrogen leaching from young lysimeter-grown orange trees. J. Irrig. Drain. Eng. 133: 350-358.

Bondarenko, S. and J. Gan. 2004. Degradation and sorption of selected organophosphate and carbamate insecticides in urban stream sediments. Environ. Toxicol. Chem. 23:1809-1814.

Brand, M.H., R.J. McAvoy, and E.G. Corbett. 1993. Nitrate loading to the soil profile underlying two containerized nursery crops supplied controlled release fertilizer. J. Environ. Hort. 11:82-85.

California Department of Food and Agriculture. 2007. California agricultural resource directory: Agricultural statistical review. 10 Mar. 2008. <http:// www.cdfa.ca.gov/files/pdf/card/ ResDir07_Overview.pdf>.

Colangelo, D.J. and M.H. Brand. 2001. Nitrate leaching beneath a containerized nursery crop receiving trickle or overhead irrigation. J. Environ. Qual. 30:1564-1574.

Gan, J., S.J. Lee, W.P. Liu, D.L. Haver, and J.N. Kabashima. 2005. Distribution and persistence of pyrethroids in runoff sediments. J. Environ. Qual. 34:836-841. 
Graves, G.A., Y. Wan, and D.L. Fike. 2004. Water quality characteristics of storm water from major land uses in south Florida. J. Amer. Water Resour. Assoc. 40:1405-1419.

He, Z.L., D.V. Calvert, A.K. Alva, D.J. Banks, and Y.C. Li. 2000. Nutrient leaching potential of mature grapefruit trees in a sandy soil. Soil Sci. 165:748758 .

He, Z.L., M.K. Zhang, P.J. Stofella, X.E. Yang, and D.J. Banks. 2006. Phosphorus concentration and loads in runoff water under crop production. Soil Sci. Soc. Amer. J. 70:1807-1816.

Holmes, R.W. and V. de Vlaming. 2003. Monitoring of diazinon concentrations and loadings, and identification of geographic origins consequent to stormwater runoff from orchards in the Sacramento River watershed, USA. Environ. Monit. Assess. 87:57-79.

Joyce, B.A., W.W. Wallender, T. Angermann, B.W. Wilson, I. Werner, M.N. Oliver, F.G. Zalom, and J.D. Henderson. 2004. Using infiltration enhancement and soil water management to reduce diazinon in runoff. J. Amer. Water Resour. Assoc. 40:10631070.

Kabashima, J.N., S.J. Lee, D.L. Haver, K.S. Goh, L.S. Wu, and J. Gan. 2004. Pesticide runoff and mitigation at a commercial nursery site, p. 213-230. In: J. Gan, P.C. Zhu, S.D. Aust, and A.T. Lemley (eds.). Pesticide decontamination and detoxification. ACS Symposium series 863. Amer. Chem. Soc., Washington, DC.

Lea-Cox, J.D., J.P. Syvertsen, and D.A. Graetz. 2001. Springtime ${ }^{15}$ nitrogen uptake, partitioning, and leaching losses from young bearing citrus trees of differing nitrogen status. J. Amer. Soc. Hort. Sci. 126:242-251.

Mangiafico, S.S., J. Newman, D. Merhaut, J. Gan, L. Wu, J. Lu, B. Faber, and R. Evans. 2008. Detention and recycling basins for managing nutrient and pesticide runoff from nurseries. HortScience 43:393-398.

McAvoy, R.J. 1994. Nitrate nitrogen movement through the soil profile beneath a containerized greenhouse crop irrigated with two leaching fractions and two wetting agent levels. J. Amer. Soc. Hort. Sci. 119:446-451.

McAvoy, R.J., M.H. Brand, E.G. Corbett, J.W. Bartok, Jr., and A. Botacchi. 1992. Effect of leachate fraction on nitrate loading to the soil profile underlying a greenhouse crop. J. Environ. Hort. 10:167-171.
Mokry, L.E. and K.D. Hoagland. 1990. Acute toxicities of five synthetic pyrethroid insecticides to Daphnia magna and Ceriodaphnia dubia.. Environ. Toxicol. Chem. 9:1045-1051.

Nowell, L.H. and E.A. Resek. 1994. National standards and guidelines for pesticides in water, sediment, and aquatic organisms: Application to water-quality assessments. Rev. Environ. Contam. Toxicol. 140:1-164.

Paramasivam, S., A.K. Alva, A. Fares, and K.S. Sajwan. 2001. Estimation of nitrate leaching in an entisol under optimum citrus production. Soil Soc. Amer. J. 65:914-921.

Quiñones, A., B. Martínez-Alcántara, and F. Legaz. 2007. Influence of irrigation system and fertilization management on seasonal distribution of $\mathrm{N}$ in the soil profile and on $\mathrm{N}$-uptake by citrus trees. Agr. Ecosyst. Environ. 122:399-409.

Ribaudo, M. and R. Johansson. 2006. Water quality: Impacts of agriculture, $\mathrm{p}$. 33-41. In: Agricultural resources and environmental indicators2006 edition. 29 Apr. 2008. <http://www.ers.usda.gov/publications/arei/eibl6/eibl6_2-2.pdf>.

Siepmann, S. and B. Finlayson. 2002. Water quality criteria for diazinon and chlorpyrifos. 28 Mar. 2008. <http://www.waterboards. ca.gov/sandiego/tmdls/tmdl_files/chollas\% 20 creek\%20 diazinon/Appendices / Appendix\%20D.\%20Water\%20Quality\%20 Criteria $\% 20$ for $\% 20$ Diazinon $\% 20$ by $\% 20$ DFG.pdf $>$.

Teh, S.J., D. Deng, I. Werner, F. Teh, and S.S. Hung. 2005. Sublethal toxicity of orchard stormwater runoff in Sacramento splitttail (Pogonichthys macrolepidotus) larvae. Mar. Environ. Res. 59:203-216.

U.S. Environmental Protection Agency. 1979. Methods for the chemical analysis of water and wastes EPA/600/4-79/ 020. Environ. Monitoring Lab., Office Res. Dev., Washington, DC.

U.S. Environmental Protection Agency. 1993. Methods for the determination of inorganic substances in environmental samples EPA/600/R-93/100. Environ. Monitoring System Lab., Washington, DC.

U.S. Environmental Protection Agency. 1997. Test methods for evaluating solid waste, physical/chemical methods, third edition, SW-846. 23 May 2008. <http:// www.epa.gov/epaoswer/hazwaste/test/ main.htm>.

U.S. Environmental Protection Agency. 2000a. Ambient water quality criteria recommendations: Rivers and streams in nutrient ecoregion III. EPA 822-B-00-
016. 28 Mar. 2008. <http://epa.gov/ waterscience/criteria/nutrient/ecoregions/ rivers/rivers_3.pdfs.

U.S. Environmental Protection Agency. 2000b. Guidance for data quality assessment practical methods for data analysis EPA QA/G-9 EPA/600/R-96/084. 29 Apr. 2008. <http://www.epa.gov/quality/ qs-docs/g9-final.pdf>.

U.S. Environmental Protection Agency. 2006. National recommended water quality criteria. 28 Mar. 2008. <http:// www.epa.gov/waterscience/criteria/ nrwqc-2006.pdf>.

U.S. Health and Human Services. 1994. Toxicological profile for chlordane. 7 May 2008. <http://www.atsdr.cdc.gov/tox profiles/tp31.pdf>.

U.S. Health and Human Services. 2002. Toxicological profile for DDT, DDE, DDD. 7 May 2008. <http://www.atsdr. cdc.gov/toxprofiles/tp35.pdf>.

Ventura County Agricultural Commissioner. 2008. Public records and downloads: Pesticide use data. 7 July 2008. <http:// portal.countyofventura.org/portal/page? pageid=826,1101429\&_dad=portal\&_ schema $=$ PORTAL $>$.

Werner, I., F.G. Zalom, M.N. Oliver, L.A. Deanovic, T.S. Kimball, J.D. Henderson, B.W. Wilson, W. Krueger, and W.W. Wallender. 2004. Toxicity of storm-water runoff after dormant spray application in a french prune orchard, Glenn County, California, USA: Temporal patterns and the effect of ground covers. Environ. Toxicol. Chem. 23:2719-2726.

Wu, L., J.M. Baker, and R.R. Allmaras. 1995. Numerical and field evaluation of soil water sampled by suction lysimeters. J. Environ. Qual. 24:147-152.

Yeager, T., R. Wright, D. Fare, C. Gilliam, J. Johnson, T. Bilderback, and R. Zondag. 1993. Six state survey of container nursery nitrate nitrogen runoff. J. Environ. Hort. 11:206-208.

Yu, S., Z.L. He, P.J. Stoffella, D.V. Calvert, X.E. Yang, D.J. Banks, and V.C. Baligar. 2006. Surface runoff phosphorus (P) loss in relation to phosphatase activity and soil $\mathrm{P}$ fractions in Florida sandy soils under citrus production. Soil Biol. Biochem. 38:619-628.

Zotarelli, L., J.M. Scholberg, M.D. Dukes, and R. Muñoz-Carpena. 2007. Monitoring of nitrate leaching in sandy soils: Comparison of three methods. J. Environ. Qual. 36:953962 . 